\title{
ISOLASI DAN IDENTIFIKASI BAKTERI ENDOFIT RIMPANG TEMULAWAK (Curcuma xanthorrhiza Roxb.) SEBAGAI PENGHASIL SENYAWA ANTIFUNGI TERHADAP Candida albicans
}

\author{
Alvi Milliana dan Wahyu Safitri \\ Jurusan Biologi, Fakultas Sains dan Teknologi UIN Maliki Malang \\ Email: alvimilliana@yahoo.com
}

\begin{abstract}
ABSTRAK
Infectious diseases in humans by microbes in developing countries including Indonesia remains a major problem. Forty-three percent of deaths in developing countries are caused by infections. Candida is a yeast species that often cause opportunistic infections. Disease caused by Candida can affect the mouth, vagina, skin, nails, lungs, sometimes can cause septicemia, endocarditis and meningitis. Rising yeast-leavened which has resistance to antifungal compounds that exist, encourage researchers continue to discover new compounds which have antifungal properties. In addition, the side effects caused by the use of antifungal drugs, causing people still expect the natural ingredients that can be used as an alternative treatment. According to WHO, $80 \%$ of the world's population still relies on traditional medicine, including the use of drugs from plants, one of which is the use of turmeric plant (Curcuma zanthorriza). Bioactive compounds of plants that are antifungal generally are volatile oil, aldehyde and phenol compounds. The existence of endophytic microbes in plants have economic significance for the industry favorable treatment. Endophytic microbes easily grown, have a shorter life cycle than the plant and capable of producing bioactive compounds similar to the host plant. Therefore, it is necessary to study the potential of endophytic bacteria ginger rhizome (C. xanthorrhiza) as a producer of Candida albicans antifungal compounds. This study uses ginger rhizome obtained from Stone and Pasuruan. After the isolation of microbes from ginger rhizome, further purification by means of subcultures. The endophytic microbial isolates gram staining and identification of bacteria. The result is a gram-positive bacterium Actinomyces viscosus, Bacillus brevis gram-positive bacteria and gram-negative bacteria Pseudomonas stutzeri. Then do the production of antifungal metabolites produced by endophytic bacteria and $C$. albicans antifungal test Paper Disc Diffusion method. The result looks the inhibition zone with a diameter of $4 \mathrm{~mm}, 15 \mathrm{~mm}$ and $45 \mathrm{~mm}$.

Keywords: Curcuma xanthorrhiza, endophytic bacteria, antifungal activity
\end{abstract}

\section{PENDAHULUAN}

Penyakit infeksi pada manusia oleh mikroba di Negara berkembang termasuk Indonesia masih menjadi masalah besar (Susanti, 2008). Penyakit infeksi telah menyebabkan kematian 13 juta orang di seluruh dunia setiap tahun terutama di Negara-negara berkembang seperti Indonesia. Empat puluh tiga persen kematian di Negara-negara berkembang disebabkan oleh infeksi (Syaifuddin, 2004). Spesies Candida merupakan salah satu spesies khamir yang sering menyebabkan infeksi. Candida adalah anggota flora normal terutama saluran pencernaan, selaput mukosa, saluran pernafasan, vagina, uretra, kulit, di bawah kuku tangan dan kaki. Candida bersifat oportunis. Penyakit yang disebabkan oleh Candida dapat menyerang mulut, vagina, kulit, kuku dan paru, kadang- kadang dapat menyebabkan septikemia, endocarditis atau meningitis (Ridawati, dkk, 2011).

Timbulnya mikroorganisme patogen yang resisten terhadap antimikroba semakin meningkat. Resistensi antibiotik telah menjadi masalah klinik dan kesehatan masyarakat sampai saat ini (Levy, 2004; Rosana dkk, 1999). Penggunaan senyawa antifungal dari kelompok poliena seperti nistatin, amfoterisin, natamisin, kelompok imidazol dan triazol telah banyak digunakan dalam dunia medis untuk pengobatan infeksi akibat khamir. Meningkatnya khamir-khamir yang memiliki resistensi terhadap senyawa antifungal yang ada, mendorong peneliti terus melakukan eksplorasi senyawa baru yang memiliki sifat antifungal. Selain itu, efek samping yang ditimbulkan akibat penggunaan obat antibiotik, menyebabkan masyarakat tetap mengharapkan bahan-bahan alami yang dapat digunakan 
sebagai pengobatan alternatif (Ridawati, dkk, 2011).

Tanaman telah diketahui merupakan salah satu sumber daya yang sangat penting dalam pengbatan dan upaya mempertahankan kesehatan masyarakat. Menurut WHO (World Health Organization), $80 \%$ penduduk dunia masih bergantung pada pengobatan tradisional termasuk penggunaan obat dari tanaman (Izza, 2011). Indonesia kaya akan tumbuhan obat, salah satu diantaranya adalah dari marga Curcuma yang tergolong ke dalam suku temutemuan Zingiberaceae. Curcuma banyak dimanfaatkan sebagai antimikroba karena kandungan senyawa aktifnya mampu mencegah pertumbuhan mikroba. Tanaman ini terdiri dari beberapa spesies diantaranya $C$. xanthorrhiza (temulawak), C. domestica (kunyit), C. mangga (temu mangga), C. zedoaria (temu giring) dan C.aeruginosa (temu hitam) (Tjitrosoepomo, 1994).

Berdasarkan hasil penelitian Adila dkk (2013) yang menguji ekstrak enam jenis rimpang Curcuma spp., yang paling besar potensinya dalam menghambat mikroba uji adalah $C$. xanthorrhiza (temulawak). Senyawa antimikroba yang terdapat dalam rimpang Curcuma yaitu minyak atsiri, alkaloid, flavonoid, tannin, kurkuminoid dan terpenoid (Rukmana, 2004). Senyawa flavonoid mampu merusak dinding sel bakteri (Heinrich et al, 2009); menghambat pembentukan protein sehingga menyebabkan kematian sel (Sundari et al, 1998). Senyawa alkaloid mempu mendenaturasi protein sehingga merusak aktivitas enzim dan menyebabkan kematian sel (Robinson, 1991). Senyawa tannin juga dapat merusak membrane sel dan dapat merusak pembentukan konidia jamur (Cowan, 1999). Senyawa bioaktif tanaman yang bersifat antifungal umumnya adalah minyak atsiri, senyawa aldehida dan senyawa fenol (Ridawati, 2011).

Rimpang temulawak telah digunakan secara luas dalam rumah tangga dan industri, termasuk industri obat-obatan. Hal ini memerlukan teknik pengolahan yang baik untuk menjaga mutunya sehingga membutuhkan biaya yang tinggi dan banyak mengalami kendala ketika akan dikembangkan dalam skala industri. Oleh karena itu diperlukan alternatif pencarian bahan bioaktif yang lebih murah dan tidak mengganggu lingkungan. Salah satunya adalah dengan memanfaatkan mikroorganisme yang ada pada tumbuhan yang disebut sebagai mikroba endofit (Petrini, 1992). Mikroba endofit adalah mikroba yang hidup dalam jaringan tanaman tanpa menimbulkan bahaya dan dapat diisolasi dari jaringan tanaman (Hallman et al, 1997).

Mikroba endofit dapat ditemukan pada berbagai jaringan tanaman, diantaranya biji, ovula, buah, batang, akar, umbi akar dan daun. Mikroba endofit mempunyai arti ekonomis karena mampu menghasilkan senyawa bioaktif yang sangat potensial untuk dikembangkan menjadi obat. Hal ini karena mikroorganisme merupakan organisme yang mudah ditumbuhkan, memiliki siklus hidup yang pendek daripada tanaman dan dapat menghasilkan senyawa bioaktif dalam jumlah besar dengan metode fermentasi (Izza, 2011). Mikroba endofit di dalam medium fermentasi akan menghasilkan senyawa sejenis yang terkandung pada tanaman inang dengan bantuan aktivitas enzim (Shibuya et al, 2005). Oleh karena itu, isolasi mikroorganisme endofit yang dapat memproduksi metabolit sekunder dari tanaman inangnya merupakan sebuah peluang besar dimasa mendatang sehingga Indonesia dapat meminimalisir impor antibiotik yang mencapai Rp. 81,6 sampai Rp. 122,4 miliar per tahun (Izza, 2011).

Menurut Radji (2005) mikroba endofit yang diisolasi dari suatu tanaman obat dapat menghasilkan metabolit sekunder sama dengan tanaman aslinya atau bahkan dalam jumlah yang lebih tinggi, sehingga kita tidak perlu menebang tanaman aslinya untuk diambil simplisisa. Oleh karena itu diperlukan kajian potensi bakteri endofit rimpang temulawak $(C$. xanthorrhiza) sebagai penghasil senyawa antifungi $C$. albicans serta bakteri apa saja yang dapat diisolasi dari rumpang temulawak (C. xanthorrhiza).

\section{BAHAN DAN METODE}

Penelitian ini menggunakan bahan rimpang temulawak (C. xanthorrhiza) yang diperoleh dari dua daerah yaitu Batu dan Pasuruan. Sedangkan fungi yang digunakan adalah $C$. albicans yang diperoleh dari Laboratorium Mikrobiologi Universitas Brawijaya. Setelah diperoleh rimpang temulawak (C. xanthorrhiza), tahap pertama penelitian adalah isolasi bakteri endofit dari rimpang temulawak. Sampel rimpang temulawak dipotong sepanjang kurang lebih 10 $\mathrm{cm}$, dicuci dengan air mengalir selama 5 menit dan dilakukan sterilisasi permukaan secara 
bertahap dengan cara direndam ke dalam etanol $75 \%$ sebanyak $10 \mathrm{ml}$ selama 5 menit, dilanjutkan ke dalam sodium hipoklorit (NaOCl) 6\% sebanyak $10 \mathrm{ml}$ selama 30 detik dan dibiarkan kering. Kemudian sampel direndam kembali ke dalam etanol $75 \%$ sebanyak $10 \mathrm{ml}$ selama 1 menit. Setelah itu dibilas dengan aquades steril selama 1 menit dan diulang

dua kali. Potongan sampel yang sudah disterilkan, dikeringkan dan dibelah secara longitudinal menjadi dua bagian secara aseptis. Setiap bagian dalam potongan ditempatkan masing-masing pada cawan petri yang berisi media nutrient agar (NA) yang diberi suplemen nystatin $100 \mu \mathrm{g} / \mathrm{ml}$ dan diinkubasi pada suhu kamar $\left(27^{\circ} \mathrm{C}\right)$ sebagai kontrol. Pengamatan dilakukan setiap hari sampai tampak pertumbuhan koloni bakteri endofit yang memperlihatkan warna putih, kuning atau hitam (Strobel, 2000; Rosana, 2001; Utami, 2011).

Bakteri endofit yang tumbuh pada media NA, dimurnikan pada media lempeng dan agar miring NA. Bakteri yang tumbuh pada media isolasi NA, disubkultur pada media lempeng NA pada suhu $35^{\circ} \mathrm{C}$ selama $24-48$ jam sampai diperoleh koloni yang murni. Koloni murni kemudian dipindahkan ke media agar NA miring dan diinkubasi pada suhu $35^{\circ} \mathrm{C}$ selama 24-48 jam. Setiap isolat bakteri endofit dibuat dua pada media agar miring, masingmasing dipergunakan sebagai working culture dan stock culture.

Biakan murni bakteri endofit yang ditumbuhkan pada media lempeng NA, diinkubasi pada suhu $35^{\circ} \mathrm{C}$ selama 24 jam. Preparat yang dibuat dari koloni bakteri yang tumbuh diwarnai dengan pewarnaan Gram, kemudian diamati di bawah mikroskop dengan pembesaran 1000x. Berdasarkan hasil pewarnaan Gram, dilakukan uji biokimiawi untuk identifikasi lanjutan. Uji dengan Mikrobact dilakukan terhadap bakteri berbentuk batang Gram negatif yang sebelumnya telah dilakukan tes oksidase memakai oksidase strip. Bakteri Gram positif berbentuk batang dan kokus diuji dengan cara konvensional, memakai gula-gula glukosa, laktosa, maltose, manitol dan sakarosa serta agar semi solid, sitrat, dan kertas oksidase. Tahap selanjutnya adalah produksi metabolit bakteri endofit. Produksi metabolit antimikroba oleh bakteri endofit dilakukan dengan cara menumbuhkannya di dalam media MHB (Muller-Hinton Broth). Koloni bakteri endofit yang telah diinkubasi pada media lempeng NA selama 24-48 jam pada suhu $35^{\circ} \mathrm{C}$, diambil satu sengkelit dan dipindahkan ke dalam $5 \mathrm{ml}$ media MHB, kemudian dilarutkan memakai tube-stirrer sampai mencapai kekeruhan 0,5 McFarland. Suspense koloni bakteri endofit dipindahkan sebanyak $1 \mathrm{ml}$ ke dalam $9 \mathrm{ml}$ medium MHB pada $50 \mathrm{ml}$ tabung Erlenmeyer, diinkubasi pada suhu $30^{\circ} \mathrm{C}$ menggunakan shaker incubator 130 rpm selama 48 jam. Setelah proses fermentasi selesai, masing-masing medium pertumbuhan di sentrifugasi $2000 \mathrm{~g}(3800 \mathrm{rpm}) 4^{\circ} \mathrm{C}$ selama 20 menit. Penyaringan supernatan hasil fermentasi isolat bakteri endofit meggunakan kertas saring whatman $0,22 \mu \mathrm{m}$. Supernatant yang diperoleh dipergunakan untuk pengujian aktivitas antimikroba.

Persiapan uji antifungi dilakukan dengan cara menumbuhkan jamur uji $C$. albicans pada media lempeng NA dan diinkubasi selama 24 jam pada suhu $35^{\circ} \mathrm{C}$. Isolat bakteri yang sudah tumbuh, diambil masing-masing satu sengkelit ose dan dicampur dengan $5 \mathrm{ml}$ media NB dampai mencapai kekeruhan 0,5 McFarland.

Metode Difusi Kertas (Paper Disc Diffusion) dilakukan dengan cara menginokulasikan $1 \mathrm{ml}$ jamur uji ke dalam 10 $\mathrm{ml}$ media MHA steril suhu $40-45^{\circ} \mathrm{C}$, kemudian dituangkan ke dalam cawan petri steril. Setelah padat, diletakkan kertas saring whatman steril ukuran $6 \mathrm{~mm}$. secara aseptik, kertas cakram yang sudah disterilkan direndam di dalam 50 $\mu \mathrm{m}$ supernatan kultur bakteri endofit selama 3 hari. Kertas cakram diambil dengan menggunakan pinset steril dan diletakkan di atas medium uji aktivitas antimikroba (media lempeng MHA). Sebagai kontrol positif digunakan cakram nistatin $1 \%$, kloramfenikol dan kontrol negatif digunakan cakram kosong steril. Kemudian diinkubasi selama 18-24 jam pada suhu $37^{\circ} \mathrm{C}$. Setelah masa inkubasi selesai, dilakukan pengukuran terhadap zona jernih yang terbentuk dan diukur diameternya. Sampel yang mempunyai potensi menghasilkan zat antimikroba ditunjukkan dengan adanya zona jernih (Utami, 2008).

\section{HASIL DAN PEMBAHASAN}

Isolasi mikroba endofit dari rimpang temulawak dilakukan dengan mengambil potongan rimpang temulawak yang telah disterilkan permukaannya dan diletakkan pada media lempeng NA. Hasil isolasi mikroba 
endofit dari rimpang temulawak dapat dilihat

pada gambar 1

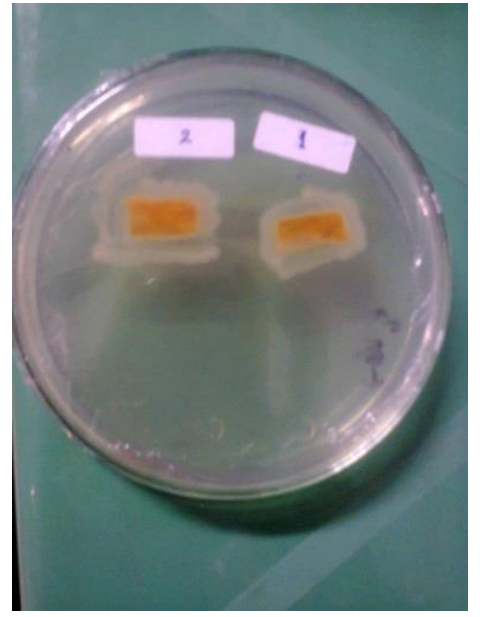

(a)

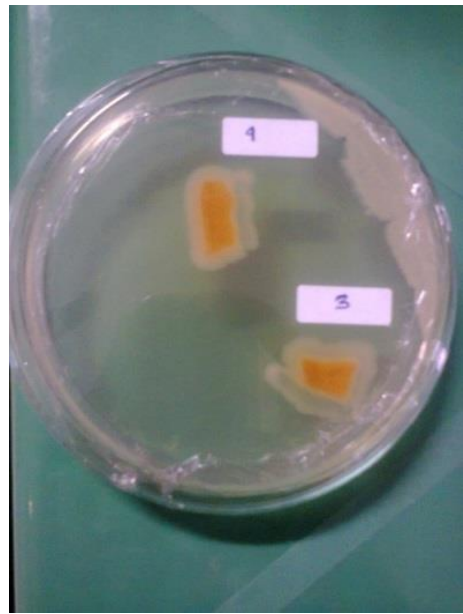

(b)

Gambar 1. Hasil isolasi mikroba endofit dari rimpang Temulawak

Keterangan: (a)Temulawaak dari lokasi Batu, (b) Temulawak dari lokasi Pandaan

Setelah didapatkan isolate mikroba endofit tersebut lalu dimurnikan pada media lempeng dan agar miring NA. Bakteri yang tumbuh pada media isolasi NA, disubkultur pada media lempeng NA. Hasil pemurnian mikroba tampak pada gambar 2 berikut

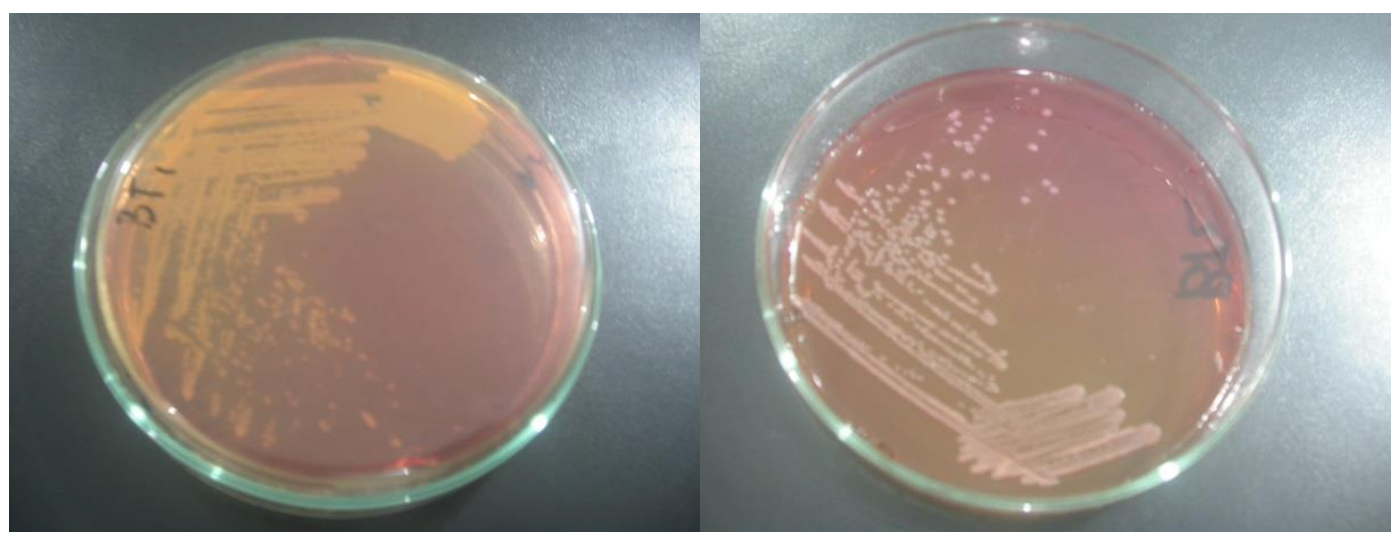

(a)

(b)

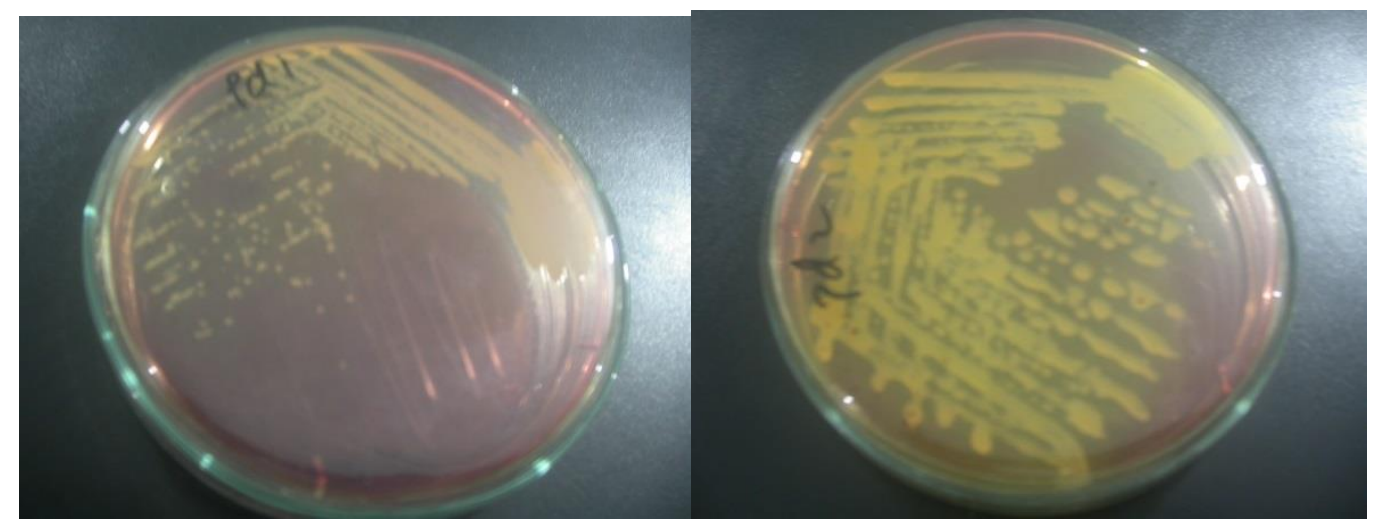

(c)

(d)

Gambar 2 Hasil pemurnian mikroba endofir rimpang temulawak

Keterangan: (a)Temulawak dari lokasi Batu 1, (b) Temulawak dari lokasi Batu 2, (c)

Temulawak dari lokasi Pandaan 1, (d) Temulawak dari lokasi Pandaan 2 
Setelah mikroba endofit dimurnikan, kemudian dilakukan identifikasi mikroba endofit yang tumbuh. Hasil identifikasi mikroba endofit tersebut adalah sebagai berikut:

\begin{tabular}{lc}
\hline KODE ISOLAT & Pd1 \\
\hline JENIS TES & HASIL \\
\hline BGP & POSITIF \\
\hline Spora & NEGATIF \\
\hline Koloni Filamentous & POSITIF \\
\hline Diftroid sel & POSITIF \\
\hline Warna Koloni krem & POSITIF \\
\hline UJI FISIOLOGIS & NEGATIF \\
\hline Katalase & NEGATIF \\
\hline Indol & POSITIF \\
\hline NO3 --> NO2 & POSITIF \\
\hline Metil Red & POSITIF \\
\hline Voges-Proskouer & NEGATIF \\
\hline H2S & NEGATIF \\
\hline TSI & NEGATIF \\
\hline Urease & NEGATIF \\
\hline Starch hydrolysis & NEGATIF \\
\hline Gelatin hydrolysis & NEGATIF \\
\hline FERMENTASI KARBOHIDRAT & POSITIF \\
\hline Arabinosa & POSITIF \\
\hline Fruktosa & POSITIF \\
\hline Glukosa & POSITIF \\
\hline Inositol & POSITIF \\
\hline Laktosa & NOSITIF \\
\hline Maltosa & NESITIF \\
\hline Mannitol & NOSITIF \\
\hline Raffinosa & POSITIF \\
\hline Rhamnosa & \\
\hline Salicin & \\
\hline Sorbitol & \\
\hline Sukrosa & \\
\hline Xylosa & \\
\hline DX LAB. & \\
\hline
\end{tabular}




\begin{tabular}{|c|c|}
\hline KODE ISOLAT & Pd2 \\
\hline JENIS TES & HASIL \\
\hline BGP & POSITIF \\
\hline Spora & POSITIF \\
\hline \multicolumn{2}{|c|}{ FERMENTASI GULA-GULA } \\
\hline Glukosa & POSITIF \\
\hline Xylosa & NEGATIF \\
\hline Mannitol & NEGATIF \\
\hline Laktosa & NEGATIF \\
\hline Sukrosa & NEGATIF \\
\hline Maltosa & POSITIF \\
\hline Arabinosa & NEGATIF \\
\hline \multicolumn{2}{|l|}{ SUHU PERTUMBUHAN } \\
\hline $25^{0} \mathrm{C}$ & POSITIF \\
\hline $37^{\circ} \mathrm{C}$ & POSITIF \\
\hline $40^{\circ} \mathrm{C}$ & POSITIF \\
\hline $55^{\circ} \mathrm{C}$ & POSITIF \\
\hline \multicolumn{2}{|l|}{ TUMBUH DI } \\
\hline Nutrient Broth & POSITIF \\
\hline MCA & NEGATIF \\
\hline TSI & $\mathrm{A} / \mathrm{A}, \mathrm{H} 2 \mathrm{~S}-$ \\
\hline CITRAT & NEGATIF \\
\hline INDOL & NEGATIF \\
\hline MR & NEGATIF \\
\hline VP & NEGATIF \\
\hline $\mathrm{NaCl} 7 \%$ & NEGATIF \\
\hline Motilitas & POSITIF \\
\hline Starch hydrolysis & NEGATIF \\
\hline PENICILLIN & SENSITIV \\
\hline BETA-HEMOLISA & POSITIF \\
\hline Katalase & POSITIF \\
\hline Oksidase & POSITIF \\
\hline Reduksi Nitrat & NEGATIF \\
\hline Reduksi Meth. Blue & NEGATIF \\
\hline DX LAB. & B. brevis \\
\hline
\end{tabular}




\begin{tabular}{|c|c|}
\hline KODE ISOLAT & Bt1 \\
\hline JENIS TES & HASIL \\
\hline BGP & POSITIF \\
\hline Spora & NEGATIF \\
\hline Koloni Filamentous & POSITIF \\
\hline Diftroid sel & POSITIF \\
\hline Warna Koloni krem & POSITIF \\
\hline \multicolumn{2}{|l|}{ UJI FISIOLOGIS } \\
\hline Katalase & NEGATIF \\
\hline Indol & NEGATIF \\
\hline NO3 --> NO2 & POSITIF \\
\hline Metil Red & POSITIF \\
\hline Voges-Proskouer & POSITIF \\
\hline $\mathrm{H} 2 \mathrm{~S}$ & NEGATIF \\
\hline TSI & NEGATIF \\
\hline Urease & NEGATIF \\
\hline Starch hydrolysis & NEGATIF \\
\hline Gelatin hydrolisis & NEGATIF \\
\hline \multicolumn{2}{|c|}{ FERMENTASI KARBOHIDRAT } \\
\hline Arabinosa & NEGATIF \\
\hline Fruktosa & POSITIF \\
\hline Glukosa & POSITIF \\
\hline Inositol & POSITIF \\
\hline Laktosa & POSITIF \\
\hline Maltosa & POSITIF \\
\hline Mannitol & NEGATIF \\
\hline Raffinosa & POSITIF \\
\hline Rhamnosa & NEGATIF \\
\hline Salicin & POSITIF \\
\hline Sorbitol & NEGATIF \\
\hline Sukrosa & POSITIF \\
\hline Xylosa & NEGATIF \\
\hline DX LAB. & Actinomyces viscosus \\
\hline
\end{tabular}




\begin{tabular}{ll}
\hline KODE ISOLAT & \multicolumn{1}{c}{ Bt2 } \\
\hline JENIS TES & HASIL \\
\hline Spora & NEGATIF \\
\hline Oksidase & POSITIF \\
\hline Motilitas & POSITIF \\
\hline Nitrat & POSITIF \\
\hline Lysin & NEGATIF \\
\hline Ornithin & NEGATIF \\
\hline H2S & NEGATIF \\
\hline Glukosa & NEGATIF \\
\hline Manitol & NEGATIF \\
\hline Xylosa & NEGATIF \\
\hline ONPG & POSITIF \\
\hline Indole & NEGATIF \\
\hline Urease & NEGATIF \\
\hline V-P & NEGATIF \\
\hline Sitrat & NEGATIF \\
\hline TDA & NEGATIF \\
\hline Gelatin & NEGATIF \\
\hline Malonat & NEGATIF \\
\hline Inositol & NEGATIF \\
\hline Rhamnosa & NEGtzeri \\
\hline Sukrosa & NEGATIF \\
\hline Lactosa & NEGATIF \\
\hline Arabinosa & NEGATIF \\
\hline Adonitol & NEGATIF \\
\hline Raffinosa & NEGATIF \\
\hline Arginin & NEGATIF \\
\hline Katalase & NEagulase \\
\hline
\end{tabular}


Hasil pewarnaan gram dari keempat spesies mikroba endofit adalah seperti yang tampak pada gambar 3 berikut

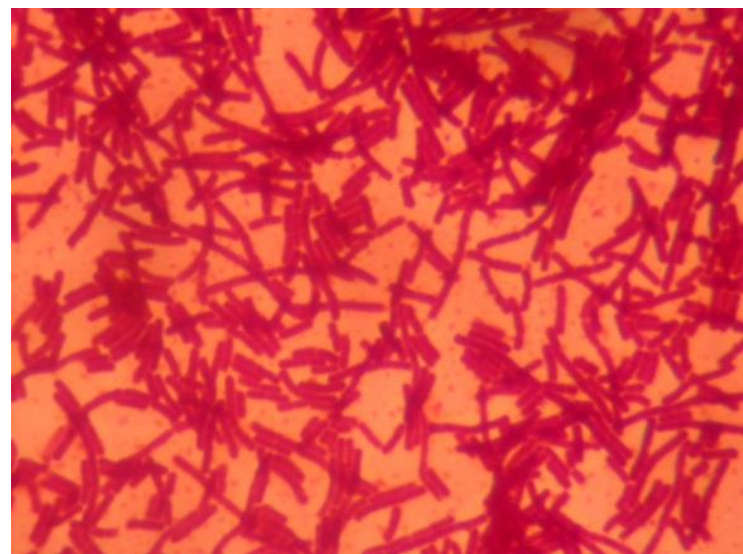

(a)

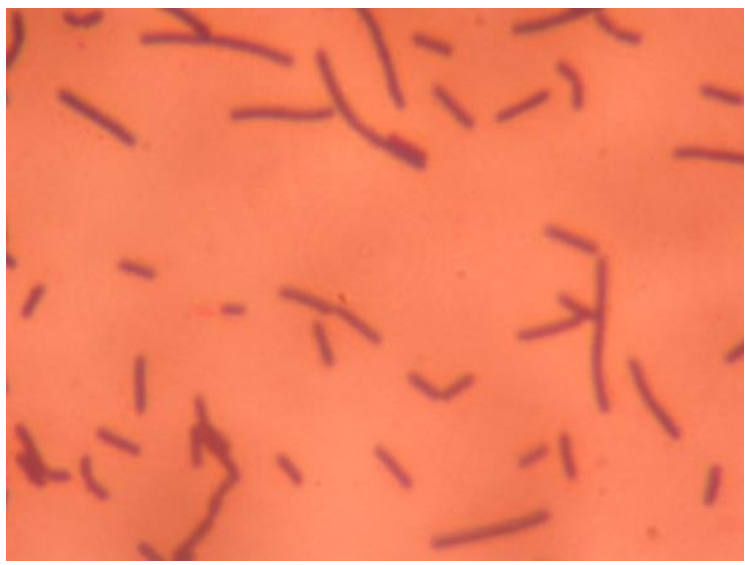

(c)

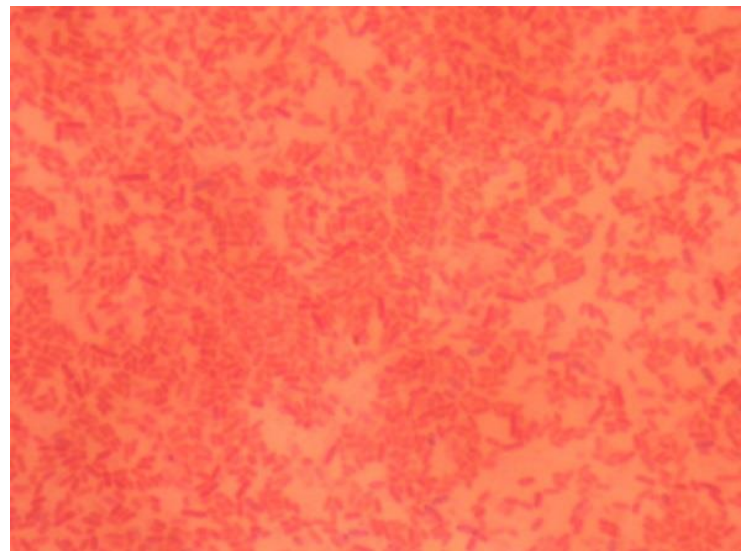

(b)

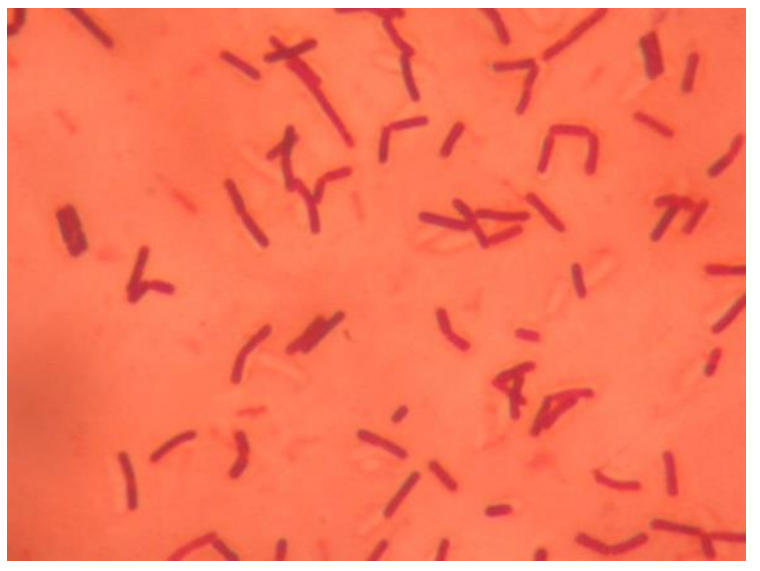

(d)

Gambar 3 Hasil pewarnaan gram mikroba endofit Keterangan:

a. Mikroba endofit dari rimpang temulawak lokasi Batu 1

b. Mikroba endofit dari rimpang temulawak lokasi Batu 2

c. Mikroba endofit dari rimpang temulawak lokasi Pandaan 1

d. Mikroba endofit dari rimpang temulawak lokasi Pandaan 2

Dari table hasil identifikasi tersebut dapat diketahui bahawa bakteri endofit yang tumbuh dari lokasi Pandaan pertama (kode Pd1) adalah A. viscosus, sedangkan dari lokasi Pandaan kedua (kode Pd2) adalah B. brevis. Sedangkan bakteri endofit yang tumbuh dari lokasi Batu pertama (kode Bt1) adalah A. viscosus dan dari lokasi Batu kedua (kode Bt2) adalah P. stutzeri. Sedangkan dari hasil pewanaan gram tampak bahwa mikroba endofit dari rimpang temulawak lokasi Batu 1 merupakan gram positif, mikroba endofit dari rimpang temulawak lokasi Batu 2 merupakan gram negatif, mikroba endofit dari rimpang temulawak lokasi Pandaan 1 merupakan gram positif dan mikroba endofit dari rimpang temulawak lokasi Pandaan 2 merupakan gram positif.

Diantara bakteri endofit yang sudah dikenal mampu memproduksi berbagai senyawa metabolit sekunder yang bermanfaat adalah dari golongan bakteri Actinomycetes. Actinomycetes telah dikenal sebagai mikrobia produsen berbagai jenis antibiotic baik antijamur maupun antibakteri. Sekitar 0\% dari antibiotik yang ada saat ini diisolasi dari Actinomycetes, dimana sebagian besar berasal dari genus Streptomyces. Berbagai jenis antibiotik yang dihasilkan bakteri ini telah 
banyak dimanfaatkan baik dalam bidang kedokteran maupun pertanian. Selain antibiotik, Actinomycetes juga mampu mensekresi berbagai senyawa lain yang berguna dalam bidang pertanian seperti zat pengatur tumbuh. enzim pendegradasi dinding sel seperti chitinase and $\beta$-glucanas serta siderophore. Empat isolat endofitik Actinomycetes dari tanaman padi lokal Lombok memiliki kemampuan untuk menghambat pertumbuhan jamur fitopatogenik Fusarium sp. and Rhizoctonia solani (Listiana dkk, 2012). Actinomyces adalah kelompok ke 17 dari bakteri yang diakui dalam edisi mutakhir Bergey's Manual, termasuk domain bakteri. Semua Actinomyces adalah gram positif dan bersifat anaerob fakultatif. Spesies Actinomyces dapat membentuk spora, dan ketika berada dalam bentuk bakteri tunggal berbentuk batang. Secara morfologi koloni, Actinomyces berbentuk seperti fungi dengan adanya jaringan hifa yang bercabang (Safinah, 2008). Bakteri endofit Actinomycetes terbukti mampu menghasilkan senyawa aktif antimikroba. Bakteri endofit ini diperoleh dari tanaman Curcuma domestica, Phaleria macrocarpa, Isotoma longiflora, dan Symplocos cocchinensis. Isolate Actinomycetes ini terbukti memiliki aktivitas antimikroba terhadap Escherichia coli, Staphylococcus aureus, Pseudomonas aeruginosa, dan Bacillus subtilis (Sunaryanto dan Mahsunah, 2013).

Bacillus brevis atau Aneurinibacillus migulanus dalam Bergey's Manual of Systematic Bacteriology (2nd ed. 2004) disebut sebagai Brevibacillus brevis.spesies Bacillus berbentuk batang, dapat membentuk endospore, bersifat aerob atau anaerob fakultatif, merupakan bakteri gram positif. Bakteri ini mampu hidup pada berbagai kondisi lingkungan. Sporanya tahan terhadap panas, dingin, radiasi, desikasi dan desinfektan. Spesies Bacillus digunakan pada berbagai bidang kedokteran, farmasi, pertanian, dan proses industry karena karakteristik fisiologi dan kemampuannya dalam memproduksi enzyme hospes, antibiotk dan metabolit lain. Basitrasin dan polymyxin adalah contoh antibiotic yang didapat dari spesies Bacillus (Turnbull, 1996)

Pseudomonas stutzeri memiliki habitat yang luas pada berbagai kondisi lingkungan, dan merupakan pathogen oportunistik pada manusia. Pseudomonas stutzeri merupakan bakteri gram negative yang berbentuk batang, dengan ukuran panjang 1-3 $\mu \mathrm{m}$ dan lebar 0,5 $\mu \mathrm{m}$ serta memiliki flagella pada salah ujungnya (monotrikus), tetapi ada pula strain yang memiliki flagella di samping tubuhnya. Bakteri ini termasuk dalam genus Pseudomonas. Koloninya memiliki bentuk yang khas yaitu tampak berkerut, berwarna merah kecoklatan, memiliki konsistensi keras, kering, mudah dipindahkan dari permukaan yang padat dan memiliki bentuk polygonal yang irregular atau zona konsentris. Organisme ini dapat bergerak (Lalucat, et al, 2006). Penelitian tentang bakteri endofit Pseudomonas stutzeri sudah pernah dilakukan sebelumnya. Pseudomonas stutzeri pernah diisolasi dari umbi tanaman Dahlia (Dahlia variabilis). Umbi tanaman dahlia mampu menghasilkan senyawa sekunder golongan fenolik, flavonoid dan saponin yang memiliki aktivitas antimikroba. Senyawa metabolit sekunder terutama senyawa antimikroba oleh isolat bakteri endofit ini dapat diproduksi dengan cara menumbuhkannya pada media fermentasi Mueller-Hinton Broth. Bakteri endofitik Pseudomonas stutzeri memiliki aktivitas antibakteri terhadap bakteri patogen E. coli dan S. aureus (Elita dkk, 2013).

Uji aktifitas antifungi dilakukan dengan metode difusi. Hasil uji aktivitas antifungi dapat dilihat pada table 1 dan gambar 2 (a, b, c, d, e dan f). Isolate mikroba endofit yang dinyatakan mempunyai aktivitas antifungi adalah jika terbentuk zona jernih di sekeliling isolat mikroba endofit yang ditumbuhkan pada media yang telah diinokulasi oleh mikroba pathogen. 


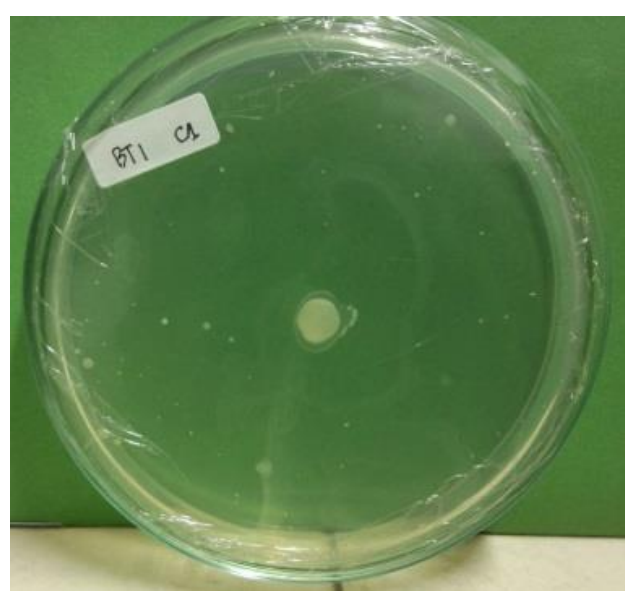

(a)

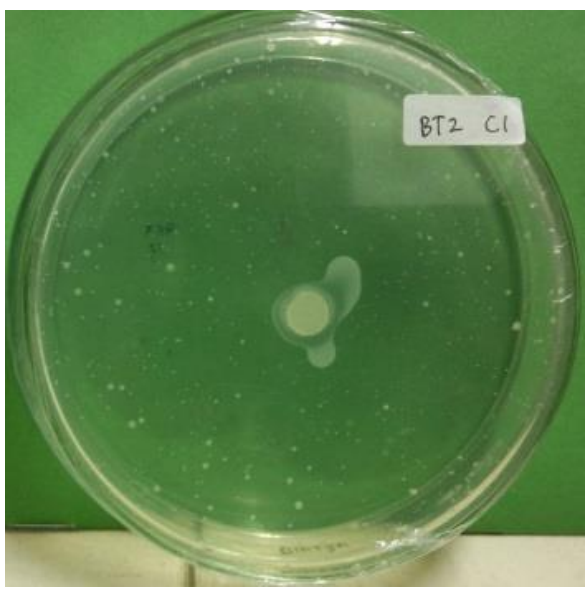

(c)

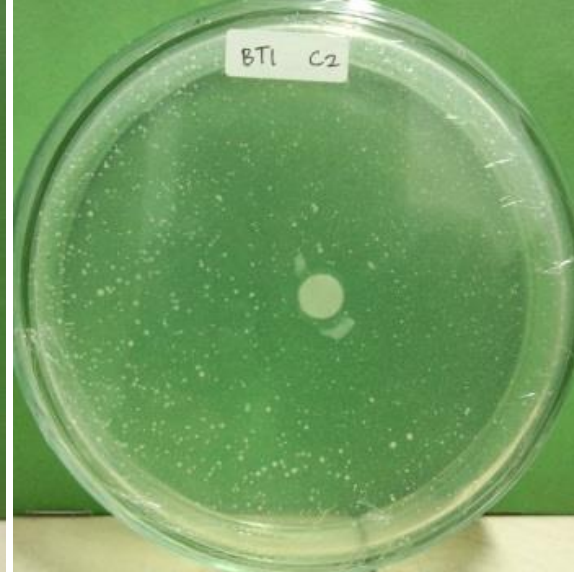

(b)

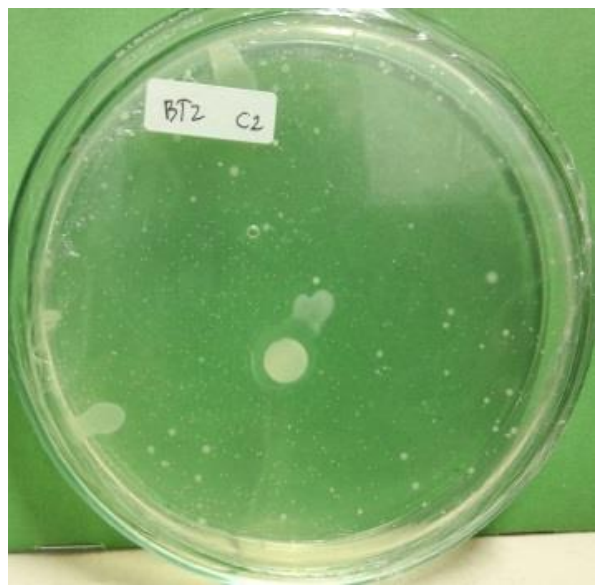

(d)

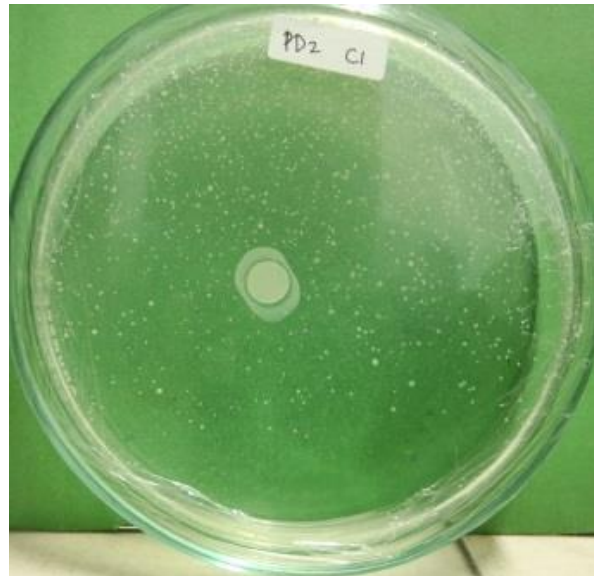

(e)

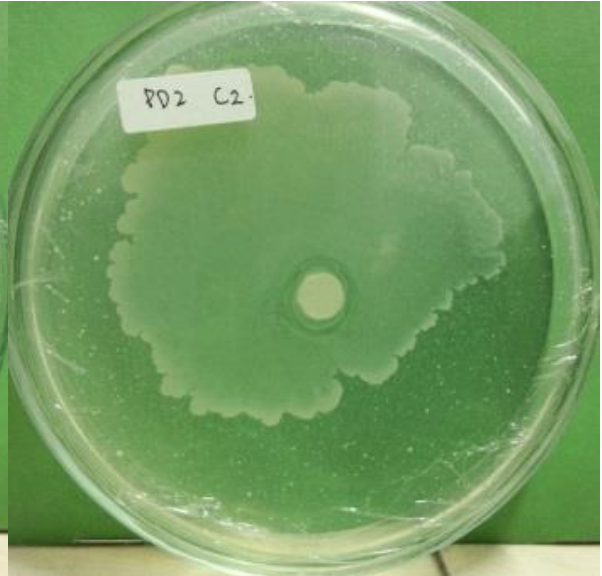

(f)

Gambar 4. Isolate bakteri yang menunjukkan aktivitas antifungi

Keterangan:

a. Isolate endofit dari lokasi Batu 1

b. Isolate endofit dari lokasi Batu 1 (duplo)

c. Isolate endofit dari lokasi Batu 2

d. Isolate endofit dari lokasi Batu 2 (duplo)

e. Isolate endofit dari lokasi Pandaan 2

f. Isolate endofit dari lokasi Pandaan 2 (duplo) 
Tabel 1. Hasil pengukuran zona hambat isolate terhadap C. albican

\begin{tabular}{cc}
\hline Kode isolate & $\begin{array}{c}\text { Luas zona hambat terhadap } \boldsymbol{C} . \\
\text { albican }(\mathbf{c m})\end{array}$ \\
\hline $\mathrm{Bt} 1$ & 0,4 \\
\hline $\mathrm{Bt} 2$ & 0,15 \\
\hline $\mathrm{Pd} 1$ & 0,4 \\
\hline $\mathrm{Pd} 2$ & 0,45 \\
\hline
\end{tabular}

Berdasarkan table 1 diperoleh hasil bahwa seluruh isolate mikroba endofit dari 2 lokasi di daerah Batu dan Pandaan memperlihatkan potensi aktivitas antifungi. Isolate dari lokasi 2 Pandaan memperlihatkan zona hambat yang paling luas yaitu $0,45 \mathrm{~mm}$, sedangkan dari lokasi 2 Batu memperlihatkan zona hambat yang paling kecil yaitu $0,15 \mathrm{~cm}$. Isolate dari lokasi 1 Batu dan lokasi 1 Pandaan memperlihatkan luas zona hambat yang sama. Isolate yang menunjukkan aktivitas antifungi lebih sempit mungkin mempunyai kandungan senyawa aktif namun jumlahnya lebih kecil atau mungkin juga mengandung senyawa aktif potensial yang lain (Simarmata, dkk, 2007).

Tabel 2. Hasil pengamatan uji antifungi pada bakteri endofit Temulawak

\begin{tabular}{cc}
\hline Kode isolate & Uji antifugi terhadap C. albican \\
\hline $\mathrm{Bt} 1$ & + \\
\hline $\mathrm{Bt} 2$ & + \\
\hline $\mathrm{Pd} 1$ & + \\
\hline $\mathrm{Pd} 2$ & + \\
\hline
\end{tabular}

Keterangan:

$+:$ terbentuk zona hambat

Bt 1 : temulawak yang diambil dari lokasi 1 Batu

Bt 2 : temulawak yang diambil dari lokasi 2 Batu

Pd 1 : temulawak yang diambil dari lokasi 1 Pandaan

Pd 2 : temulawak yang diambil dari lokasi 2 Pandaan

Berdasarkan penelitian tersebut didapatkan hasil bahwa jenis bakteri endofit yang dapat diisolasi dari rimpang temulawak (C. xanthorrhiza) dari 2 lokasi sampel di Batu dan Pandaan adalah A. viscosus, B. brevis dan $P$. stutzeri. Rimpang temulawak $(C$. xanthorrhiza) dari 2 lokasi sampel di Batu dan Pandaan menunjukkan adanya aktivitas antifungi terhadap C. albicans

Temulawak diketahui mengandung zat antimikroba, salah satu kandungannya adalah kurkumin yang dapat menghambat pertumbuhan dan mematikan mikroorganisme (Ardiansyah, 2007).Komposisi kimia dari rimpang temulawak adalah protein pati, kurkumin dan minyak atsiri. fellandrean dan turmerol. Selain itu juga mengandung kamfer, glukosida, foluymetik karbinol. Temulawak mengandung minyak atsiri seperti limonina yang mengharumkan, sedangkan kandungan flavonoidnya berkhasiat menyembuhkan radang. Minyak atsiri juga mampu membunuh mikroba. (Purnowati, 2008).

Sebagian besar komponen kimia yang berasal dari tanaman yang digunakan sebagai obat atau bahan obat merupakan metabolit sekunder. Metabolit sekunder termasuk antibiotic atau antimikroba dapa diproduksi oleh mikroorganisme endofit yang dalam habitat aslinya dapat membentuk koloni dalam jaringan tanaman. Mikroorganisme dapat ditemukan dalam batang, umbi akar dan akar tetapi tidak menyebabkan penyakit pada tanaman tersebut (Izza, 2011).

Penelitian yang dilakukan oleh Erna Listiana dkk terhadap bakteri endofit Actinomycetes dari tanaman padi local Lombok didapatkan hasil bahwa Actinomycetes dapat menghambat pertumbuhan jamur fitopatogenik 
Fusarium sp. and Rhizoctonia solani (Listiana, dkk, 2012).

Berdasarkan hasil penelitian tersebut, maka diperlukan penelitian lebih lanjut untuk mengetahui potensi antifungi bakteri endofit rimpang temulawak (C. xanthorrhiza) terhadap spesies jamur lainnyadan untuk mengetahui jenis senyawa aktif antifungi yang dihasilkan oleh bakteri endofit rimpang temulawak $(C$. xanthorrhiza).

\section{DAFTAR PUSTAKA}

Adila, R., Nurmiati, dan Anthoni, A. 2013. Uji Antimikroba terhadap Pertumbuhan Candida Albica, Staphilococcus aurens dan Eschercia coli. Jurnal Biologi, hl 6-11.

Afifah,E. 2003. Khasiat dan manfaat temulawak, rimpang penyembuh aneka penyakit. Agromedika Pustaka, Jakarta.

Aini, L. Q. dan A. L. Abadi . 2004. Keragaman Bakteri Endofitik dalam Jaringan Akar Tanaman Pisang Serta Potensi Antagonistiknya. Jurnal Ilmu-Ilmu Hayati. 16 (2): 114-115.

Batubara, R., Mohammad Rafi, Latifah K. 2005. Estimasi Kandungan Kurkumin pada Sediaan Herbal Komersial Secara Spektrofotometri Derivative. JurnalSains Kimia vol 9, No. 1,: 28-3.

Castillo UF, Strobel, Ford EJ, Hess WM, Porter $\mathrm{H}$, Jensen JB, Albert H, Robison R, Condron MAM, Teplow DB, Stevens D, Yaver D. 2002. Munumbicins, 34 wide-spectrum antibiotics produced by Streptomyces NRRL 30562, endophytic on Kennedia nigriscans. Microbiology. 148:2675-2685. developments (Review). Drugs. 53:539-549.

Cowan, M. 1999. Plant Products as Antimicrobial Agents. Clinical Microbiology (12) 4: 564-582 Hwang, J.K. 2000.

Dwidjoseputro, D. 1989. Dasar-dasar Mikrobiologi. Jakarta: Djambatan

Elita, A., Saryono, S., Christine, J. 2013. Penentuan Waktu Optimum Produksi Antimikroba dan Uji Fitokimia Ekstrak Kasar Fermentasi Bakteri Endofit Pseudomonas sp. Dari Umbi Tanaman Dahlia (Dahlia variabilis). J. Ind.Che.Acta Vol. 3 (2) Mei 2013, p. 56-62

Ezra D et al.. 2004. Coronamycins, peptide antibiotics produced by a verticillate

$\begin{aligned} & \text { Streptomyces sp. } \\ & \text { endophytic on Monstera }\end{aligned}$ sp..
Microbiology. 150:785-793.

Fatmawati, D.A. 2008. Pola Protein dan Kandungan Kurkuminoid Rimpang Temulawak (Curcuma Xanthorrhiza Roxb.). [Skripsi]. FMIPA.ITB. Bandung.

Fengxia L, Lijun S, Zhaoxin L, Xiaomei B, Yaowei F, Shu L. 2007. Isolation and identification of an endophytic strain EJS-3 producing novel fibrinolytic enzymes. Curr Microbiol. 54:435-439.

Hallman, J. Quadr-Hallman A, Mahaffee, WF, Klopper, JW. 1997. Bacterial Endophytes in Agricultural Crop. Can J Microbiol. 43: 895-914.

Hedge, B.M. 2005. Antibiotic Crisis-A Time Bomb. Jurnal Kuwait Med. 37 (2): 7981 Hansel, R. 1980. Pharmazeutische Biology, Springer-Verlag. Berlin.

Heinrich, M. 2009. Farmakognasi dan Filoterapi. Buku Kedokteran Indonesia. Jakarta.

Hallman, J. Quadr-Hallman A, Mahaffee, WF, Klopper, JW. 1997. Bacterial Endophytes in Agricultural Crop. Can J Microbiol. 43: 895-914.

Hwang, J.K. 2000. Xhantorrhizol a Potential Antibacterial Agent for Curcuma Xantorrizha Against Streptococcus Mutans. Planta Med 66: 196-197.

Izza, I. 2011. Isolasi, Karakterisasi dan Identifikasi Bakteri Endofit daari Tanaman Mahkota Dewa (Phaleria macrocarpa) yang Berpotensi Sebagai Penghasil Antimikroba. UIN Sunan Kalijaga, Yogyakarta.

Jawetz,E.,J.L. Melnick \& E.A. Adelberg. 2004. Medical Microbiology. Lange Medical Publications, Canada.

Lalucat, J., Bennasar, A., Bosch, R., GarciaValdes, E., Pallero, N.J. 2006. Biology of Pseudomonas stutzeri. Microbiology and Molecular Biology Reviews, June 2006, p. 510-547

Levy, S.B. 2002. Faktors Impacting on the Problem of Antibiotic Resistence. J. of Antimicrobial Chemotherapy. 49: 2530.

Listiana, E., Anugrahwati, D.R., Muthahanas, I. 2012. Isolasi dan Identifikasi Bakteri Endofitik Actinomycetes dari Tanaman Padi Lokal Lombok. Downloaded on February 2, 2015 
Lumyong S, Norkaew N, Ponputhachart D, Lumyong P, dan Tomita F, 2001. Isolation, Optimisation and Characterization of Xylanase from Endophytic fungi. Biotechnology for Sustainable Utilization of Biological Resources. The Tropic, 15.

Manitto, P. 1981. Biosynthesis of Natural Products. Ellis Hormood Limited. Koensoemardiyah (penterjemah). 1992. Biosintesis Produk Alami. IKIP Semarang Press.

Melo FMP, Fiore MF, Moraes LAB, Scramin S, Teixeira MA, Melo IS. 2009. Antifungal compound produced by the cassava endophyte Bacillus pumilus MAIIIM4A. Sci Agr. 66: 583-592.

Miller RV, Miller CM, Garton Kinney D et al., 1998. Ecomycins, Unique Antimucotis from Pseudomonas Virid Flava. J. Appl Microbiol; 151: 67-73.

Myers, RS. 2006. Antifungal Agents. Immunizing and Antimicrobial Agents. Spring 2006. MEDCH 401

Pelczar, M. J, Jr., and Chan E. C. S, 1986, Mikrobiologi Dasar, Edisi Kelima, Jilid I, a.b. Sri, R. H., dkk, Universitas Indonesia-Press, Jakarta. Penerbit Kanisius. Yogyakarta

Pelczar, M.J dan E.C.S Chan, 1998. Mikrobiologi. Penterjemah: Hadioetomo, R.S dan Tjitrosomo, S.L. Penerbit UI Jakarta.

Petrini OTN, Sieber LT, Viret O. 1992. Ecology, Metabolite Production and Substrate Utilization and Endhophytic Fungi. Natural Toxin.p. 185-196.

Pujiyanto S, Lestari Y, Suwanto A, Budiarti S, Darusman LK. 2012. Alphaglucosidase inhibitor activity and characterization of endophytic actinomycetes isolated from some indonesian diabetic medicinal plants. Int J Pharm Pharm Sci. 4: 327-333.

Purnomowati, Sri. 2008. Khasiat Temulawak: Tinjauan Literatur tahun 1980-1997. http://www.indofarma.co.id/index.php? option $=$ com_content\&task=view\&id=2 $1 \&$ Itemid=125. Downloaded on Agustus 31, 2008).

Qiong-Ying W, Jun-Qiang J, Guang-Xiu T, Hui Y, Zhong-Zheng G. 2012. Isolation and characterization of an antimicrobial endophytic bacterium ME-2 from mulberry twig in China. Afr J Mic Res. 6: 6462-6467

Radji, Maksum. 2005. Peranan Bioteknologi dan Mikroba Endofit dalam Pengembangan Obat Herbal. Majalah Ilmu Kefarmasian, Vol. II No. 3, 113126.

Rahman, M. 2008. Aktivitas Anti Bakteri Senyawa Hasil Biotransformasi Kurkumin Oleh Mikrob Endofil Asal Kunyit. http://repository.ip b.ac.id/bitstream/handle/123456789/14 837/ G09mnr.pdf [15 Februari 2015].

Rahmat Rukmana, Ir. 1995. Temulawak: Tanaman rempah dan obat.

Ridawati, Jenie, BSL., Djuwita, I., Sjamsuridjal, W. 2011. Aktiivitas Antifungal Minyak Atsiri Jinten Putih Terhadap Candida parapsilosis SS25, C. orthopsilosis NN14,

C. metapsilosis MP27, dan C. etchellsii MP18. Makara Sains, Vol.15 No.1, April 2011: 58-62

Robinson, T. 1991. Kandungan Organik Tumbuhan Tingkat Tinggi. ITB. Bandung.

Rosana, Y, Sjahrurachman, A., Setyaningsih, ER. Studi Resistensi N. Gonorrhoeae yang diisolasi dari Pekerja Seks Komersial di Beberapa Tempat di Jakarta. Mikrobiol Indon. 1999; 4: 6063.

Rukmana, R. 2004. Temu-temuan Apotek Hidup di Pekarangan. Kanisius. Yogyakarta.

Ryan RP, Germaine K, Franks A, Ryan DJ and Dowling DN. 2007. Minireview: Bacterial endophytes: recent developments and applications. FEMS Microbiol Lett. 278:1-9.

Safinah. 2008. Optimasi Separasi dan Purifikasi Senyawa Antibiotika yang Dihasilkan oleh Aktinomiset Endofit

Shibuya H. Agusta A, Ohashi K, Maehara S, and Simanjuntak P. 2005. Biooxidation of (/)- Catechin and (-)- Epicatechin into 3,4-Dihydroxy flavan Derivatives by the Endophytic Fungus Diaporthe sp. Isolated from a Tea Plant. Chem Pharm Bull. 53 (7): 866-7.

Sidik, Mulyono M.W., \& Muhtadi A., 1985, Temulawak (Curcuma xanthorriza Robx.), Yayasan Pengembangan Obat Bahan Alam Phytomedica, Jakarta.

Simanjuntak, P., Titik K.P., Bustanussalam, Kazuyoshi O., Hirotaka S., 2001. 
Biochemical Character of Endophyte Microbes Isolates from Cinchona Plnts..In Biotechnology for Sustainable Utilization Biological Resources in the Tropics. Vol. 15.

Simarmata, R., Lekatompessy, S., Sukimin, H. 2007. Isolasi Mikroba Endofitik daari Tanaman Obat Sambung Nyawa (Gynura procumbens) dan Analisis Potensinya sebagai Antimikroba. Berk. Penel. Hayati: 13 (85-90)

Srikandace Y, Hapsari Y, Simanjuntak P. 2007. Seleksi mikroba endofit Curcuma zedoaria dalam memproduksi senyawa kimia antimikroba. JIFI. 5(2):77-84.

Strobel GA, Hess WM, Fund E, Sidhu RS, And Yang X. 1996a. Taxol from Fungal Endophytes and the Issue of Biodeversity. J Industrial Microbiol. 17; 417-29.

Strobel GA, Yang X, Sears J, Kramer P. Sidhu RS, and Hess WM. 1996b. Taxol from Pestatiopsis Microspore an Endophytic Fungus of Taxus Wallachiana. Microbiology. 142: 435-40.

Sunaryanto, R., Mahsunah, A.H. 2013. Isolation, Purification, and Characterization of Antimicrobial Substances from Endophytic Actinomycetes. Makara J. Sci. 17/3 (2013), p. 87-92

Sundari, D., Dzulkarnain, B., Widowati, L., Astuti, Y., Adjirni., Pudjiastuti. 1998. Penelitian Tanaman Obat di Beberapa Perguruan Tinggi di Indonesia IX. Jakarta: Pusat Penelitian dan Pengembangan Farmasi, Badan Penelitian dan Pengembangan Kesehatan, Departemen Kesehatan RI.

Sunitha VH, Ramesha A, Savitha J, Srinivas C. 2012. Amylase production by endophytic fungi Cylindrocephalum sp. isolated from medicinal plant Alpinia calcarata (haw.) Roscoe. Braz J Microbiol. 2012:1213-1221.

Susanti, Ivy. 2008. Pemprov NAD Luncurkan Tahun Sanitasi Internasional. Harian Waspada Online 03 Maret 2008, diakses dari http://www.waspada.co.id tanggal 03 Maret 2008.

Syaifuddin, M. 2004. Peranan Teknik Nuklir dalam Pemberantasan Penyakit Infeksi, Puslitbang Keselamatan Radiasi dan Biomedika Nuklir-BATAN. Bulletin Alara 5 (1); 15-22.
Taechowisan T, Chuaychot N, Chanaphat S, Wanbanjob A, Shen Y. 2008. Biological activity of chemical constituents isolated from Streptomyces sp. Tc052 and endophyte in Alpinia galanga. Int J Pharm. 4:95-101.

Taechowisan T, Lumyong S. 2003. Activity of endophytic actinomycetes from roots of Zingiber officinale and Alpinia galanga against phytopathogenic fungi. Ann Microbiol. 53:291-298.

Tan, R. X. and W. X. Zou. 2001. Endophytes: A rich of functional metabolites. Nat. Prod. Rep. 18: 448-459.

Tjitrosoepomo, G. 1994. Taksonomi Tanaman Obat-obatan. UGM. Yogyakarta.

Tortora, G.J., B.R/ Funke, Christine L.C. 2001. Microbiology an Introduction. International Edition. Addison Wesley Longman, Inc. New York. Isolation, id.

Turnbull, P.C.T. 1996. Bacillus. In: Baron, S., editor. Medical Microbiology. $4^{\text {th }}$ edition. Galveston (TX): University of Texas Medical Branch at Galvaston. Chapter 15

Utami, U. 2011. Isolation, Identification and antimicrobial activities selection of endophytic bacterial from Mangrove Bruguiera Gymnorrhiza..Intern. Journal of Academic Research, vol.3, p. 187194.

Waluyo,Lud. 2008. Dasar Teknik Metode Mikrobiologi. Malang: UMM Press.

Wikipedia. 2015.2 Actinomyces. http://en.wikipedia.org/wiki/Actinomyc es. Downloaded on February 2, 2015 